\title{
Incidence of pterygium in patients admitted to a university hospital
}

\author{
Bir üniversite hastanesine başvuran hastalarda pterjiyum sıklığı
}

\author{
Fethiye Gülden Turgut ${ }^{1}$, Fırat Helvacıoğlu²
}

\begin{abstract}
Objectives: This study aimed to investigate the incidence of pterygium in a particular district of Istanbul, its association with age, and gender, and the severity of the disease.

Methods: All patients aged $\geq 30$ years referred to our outpatient clinics between January 2009 and December 2009 were included in this retrospective study. Age, gender, anterior segment photos, and findings of biomicroscopic eye examination were evaluated.
\end{abstract}

Results: The incidence of pterygium for all age groups was $2.91 \%$ (male $1.75 \%$, female $3.67 \%$ ) with an increasing incidence with age. A significant difference was detected in its incidence favoring female patients in 40-49, and $70-79$, and male patients in $\geq 80$ age groups, respectively. In addition, pterygium was seen in one $(75.4 \%)$ or both eyes $(24.6 \%)$ preferring right or left eye in $50.7 \%$, and $49.3 \%$ of the patients, respectively. Pterygium was in nasal or temporal region in $98 \%$, and $2 \%$ of the patients, respectively. The disease state in $59.9 \%$ of the patients was consistent with Stage 2 pterygium. The distance of pterygium from limbus was observed greatest in 60-69, and at a minimum in 40-49 age groups. No relationship was found between eye colour and development of pterygium.

Conclusion: The incidence of pterygium increases with age. Incidence of pterygium differs between genders but without any significant difference. Its occurrence in one or both eyes and in right and left eyes was not influenced by gender of the patients. A statistically significant impact of eye colour of the patient on the development of pterygium was not disclosed. J Clin Exp Invest 2013; 4 (4): 436-442

Key words: Pterygium, incidence, İstanbul

\section{INTRODUCTION}

Clinically, pterygium is a growth of abnormal fibrovascular tissue extending from bulbar conjunctiva towards cornea in the region of palpebral fissure [1]. Pterygium is one of ocular surface diseases, which is mostly encountered in clinical practice and most

\section{ÖZET}

Amaç: Bu çalışma, İstanbul ilinde belirli bir bölgedeki pterjiyum insidansını, yaş, cinsiyet ve hastalık şiddetini araştırmayı amaçladı.

Yöntemler: Bu retrospektif çalışmada, polikliniğimize Ocak 2009 ve Aralık 2009 tarihleri arasında başvuran 30 yaş ve üzerindeki tüm hastalar dâhil edildi. Hastaların yaş, cinsiyet, ön segment fotoğrafları, biomikroskopik göz muayenesi bulguları değerlendirildi.

Bulgular: Pterjiyumun tüm yaş grupları için prevelansının \%2,91 (erkeklerde \%1,75, kadınlarda \%3,67) olduğu; yaş arttıkça pterjiyum görülme sıklığının arttığı, 40-49 yaş grubunda ve $70-79$ yaş grubunda bayanlar lehine, 80 ve üstü yaş grubunda ise erkekler lehine anlamlı bir prevelans farkı mevcut olduğu ortaya konuldu. Ayrıca, pterjiyum $\% 75,4$ hastada tek tarafta, \%24,6 hastada ise çift tarafta; $\% 50,7$ hastada sağ gözde, $\% 49,3$ hastada sol gözde görüldü. Pterjiyum, hastaların \%98'inde nazal bölgede iken \%2'sinde temporal bölgede idi. Hastaların \%59,9' u Evre 2 pterjiyum ile uyumlu idi. Hastanın göz rengi ile pterjiyum gelişmesi arasında bir ilişki yoktu.

Sonuç: Pterjiyum gelişme riski yaş ilerledikçe yükselmektedir. Pterjiyum prevelansı cinsiyet açısından farklılık gösterse de, bu fark anlamlı düzeyde değildir. Pterjiyumun tek ya da çift gözde görülme ile sağ ya da sol gözde görülmenin cinsiyetten etkilenmediği ortaya konulmuştur. Hastanın göz renginin pterjiyum gelişimi üzerine anlamlı bir etkisinin olmadığı izlendi.

Anahtar kelimeler: Pterjiyum, insidans, İstanbul

frequently cited in the literature. In population based studies, prevalence rates of pterygium has been reported as between $4 \%$ and $29 \%[2,3]$. These rates have been found to vary between 4 and 31 percent in clinical incidence studies [3-5].

\footnotetext{
${ }^{1}$ Department of Ophthalmology, Diyarbakır Training and Research Hospital, Diyarbakır, Turkey

${ }^{2}$ Department of Ophthalmology, Faculty Of Medicine, Maltepe University, Istanbul, Turkey
}

Correspondence: Fethiye Gülden Turgut,

Department of Ophthalmology Diyarbakır Training and Research Hospital Diyarbakır, Turkey Email: fguldenturgut@gmail.com Received: 19.07.2013, Accepted: 30.07.2013

Copyright (C) JCEI / Journal of Clinical and Experimental Investigations 2013, All rights reserved 
For centuries, debates have been sustained among ophthalmologists about etiology, pathogenesis and treatment of pterygium and nowadays any precise conclusion and consensus cannot be reached about these issues. Pterygium is prevalently seen in countries where relatively higher exposure to ultraviolet light occurs. Pterygium is essentially a degenerative abnormality developed in subepithelial tissue. However, its etiology is not fully known, in recent years, limbal stem cell alterations due to exposure to ultraviolet light have been emphasized [6-8]. Besides its asymptomatic course of development, symptoms such as burning sensation, irritation, watering eyes, sensation of a foreign body and photophobia can be encountered. Besides, complaints such as decrease in visual acuity related to the disruption of refractive surface of the tear film and induction of regular and irregular astigmatism secondary to corneal retraction or closure of the visual axis can be reported [9-11].

In our country, epidemiological studies concerning eye diseases or those covering some certain regions and the whole population have not been conducted so far or they are inadequately scarce in number. This study was planned to explain the incidence of pterygium, its correlation with age and gender and the impact of age and gender on the severity of the disease in a predetermined region of Istanbul.

\section{METHODS}

This retrospective study performed by the Department of Ophthalmology in all patients aged $\geq 30$ years who consulted to our out-patient clinics between January 2009 and December 2009. The patients were evaluated as for age, gender and anterior segment photos taken by a non-midriatic fundus camera (VK-2, Kowa Optimed, Tokyo, Japan), in addition to biomicroscopic eye examination findings (to detect presence or absence of pterygium).

In our hospital, the anterior segment photos were taken in all patients as part of a routine eye examination. Patients whose anterior segment photos could not be taken because of artifacts in photos and eyelid ptosis which would preclude anterior segment examination were excluded from the studies.

Patients with pterygium were divided into 6 age groups as 30-39, 40-49, 50-59, 60-69, 70-79 and $\geq 80$ years and evaluated as for age, gender, eye involvement, location and laterality of pterygium, its distance from limbus, stage of pterygium and eye colour.
Staging of the pterygium was determined as follows: Stage 1: head of the pterygium is located in corneal limbus, Stage 2: head of the pterygium is located between the corneal limbus and the undilated pupillary margin, Stage 3: head of the pterygium is on the pupillary margin, Stage 4 : head of the pterygium extending beyond pupillary margin, Stage 5: head of the pterygium extending beyond pupilla. The study protocol was approved by the local Ethics Committee of Maltepe University, Faculty of Medicine.

For statistical analysis of the study data SPSS (Statistical Package for Social Sciences) for Windows 16.0" program was used. For the comparisons between descriptive statistical methods (mean, standard deviation, and percentile) and qualitative data chi-Square test and between quantitative parameters Mann Whitney-U test were used. The results were evaluated as statistically significant $(p<$ 0.05 ) or insignificant $(p>0.05)$ within a $95 \%$ confidence interval.

\section{RESULTS}

In our study 14169 patients who consulted to our out-patient clinics of the Department Ophthalmology were divided into 6 age groups as 30-39, 40-49, 50-59, 60-69, 70-79 and $\geq 80$ years and evaluated as for the presence of pterygium. Among 14169 cases screened for the presence of pterygium, 5121 $(36.15 \%)$ of them were female and $9048(63.85 \%)$ of them were male which demonstrated predominance of male gender $(p=0.006)$. The relatively higher number of male patients evaluated were statistically significant in the age groups of 40-49 $(p<0.001), 70-79(p=0.014)$ and $\geq 80$ years $(p=0.03)$ (Table 1).

Table 1. Evaluation of the impact of gender on pterygium in various age groups

\begin{tabular}{lccc}
\hline $\begin{array}{c}\text { Age group } \\
\text { (years) }\end{array}$ & $\begin{array}{c}\text { Male }(\mathrm{n}=9048) \\
\mathrm{n}(\%)\end{array}$ & $\begin{array}{c}\text { Female }(\mathrm{n}=5121) \\
\mathrm{n}(\%)\end{array}$ & $\mathrm{p}$ value \\
\hline $30-39$ & $12 / 2031(14.3)$ & $8 / 899(6.3)$ & 0.365 \\
$40-49$ & $33 / 2328(16.4)$ & $32 / 1139(8.0)$ & $<0.001$ \\
$50-59$ & $53 / 2204(15.5)$ & $36 / 1371(9.7)$ & 0.680 \\
$60-69$ & $55 / 1451(10.2)$ & $50 / 1051(7.4)$ & 0.234 \\
$70-79$ & $50 / 756(5.3)$ & $55 / 526(3.7)$ & 0.014 \\
$>80$ & $32 / 278(1.9)$ & $7 / 135(1.0)$ & 0.030 \\
\hline Total & $235 / 9048(63.9)$ & $188 / 5121(36.2)$ & 0.006 \\
\hline
\end{tabular}


Pterygium was observed during physical examination of 188 female $(44.45 \%)$ and 235 male $(55.55 \%)$ patients with a mean age of $61.91 \pm 13.26$ (range, $30-88$ years) years (Table 1 ).

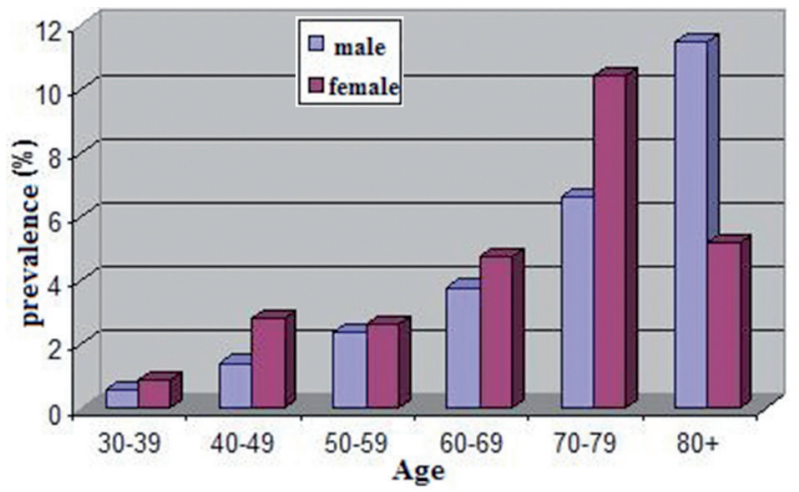

Figure 1. Distribution of incidence rates of pterygium based on age groups and genders of patients
Median incidence of pterygium in all age groups was $2.91 \%$. Median incidence rates of pterygium in male and female study populations in all age groups were $1.75 \%$ and $3.67 \%$, respectively. This gender difference was not found to be significant. A significant difference in incidence rates was found in favor of female (40-49 and 70-79 age groups) and male ( $\geq 80$ years) study populations in indicated age groups (Table 2, Figure 1).

Distribution of pterygiums in 423 patients were evaluated as for their laterality and location and unilateral $(n=319 ; 75.4 \%)$ and bilateral $(n=104 ; 24.6 \%)$ pterygiums were detected. Pterygiums were unilateral in $74.5 \%$ of the female and $76.6 \%$ of the male study participants, while bilaterality was observed in $25.5 \%$ of the female and $23.4 \%$ of the male study population (Table 3).

Table 2. Distribution of incidence rates of pterygium according to age groups and gender

\begin{tabular}{llllllllll}
\hline \multirow{2}{*}{$\begin{array}{l}\text { Age group } \\
\text { (years) }\end{array}$} & \multicolumn{1}{l}{ Male } & \multicolumn{4}{c}{ Female } & \multicolumn{4}{c}{ Male and Female } \\
\cline { 2 - 10 } & $\mathrm{n}$ & $\% \pm \mathrm{SD}$ & $95 \% \mathrm{Cl}$ & $\mathrm{n}$ & $\% \pm \mathrm{SD}$ & $95 \% \mathrm{Cl}$ & $\mathrm{n}$ & $\% \pm \mathrm{SD}$ & $95 \% \mathrm{Cl}$ \\
\hline $30-39$ & 2031 & $0.59 \pm 0.17$ & $0.23-1.40$ & 899 & $0.88 \pm 0.22$ & $0.46-1.65$ & 2930 & $0.68 \pm 0.24$ & $0.40-1.56$ \\
$40-49$ & 2328 & $1.41 \pm 0.31$ & $0.66-2.20$ & 1139 & $2.80 \pm 0.86$ & $1.45-4.56$ & 3467 & $1.87 \pm 0.81$ & $0.90-3.50$ \\
$50-59$ & 2204 & $2.40 \pm 0.51$ & $1.61-4.10$ & 1371 & $2.62 \pm 0.71$ & $1.36-4.40$ & 3575 & $2.48 \pm 0.90$ & $1.03-4.50$ \\
$60-69$ & 1451 & $3.79 \pm 0.82$ & $1.65-6.30$ & 1051 & $4.75 \pm 1.15$ & $2.59-6.48$ & 2502 & $4.19 \pm 1.30$ & $2.50-5.62$ \\
$70-79$ & 756 & $6.61 \pm 1.34$ & $3.54-7.50$ & 526 & $10.45 \pm 3.36$ & $5.56-14.50$ & 1282 & $8.19 \pm 2.43$ & $5.41-11.52$ \\
$>80$ & 278 & $11.51 \pm 4.52$ & $6.50-14.65$ & 135 & $5.18 \pm 2.01$ & $3.51-7.42$ & 413 & $9.44 \pm 3.64$ & $6.30-13.50$ \\
\hline Total & 9048 & $1.75 \pm 0.43$ & $0.69-3.64$ & 5121 & $3.67 \pm 1.86$ & $1.92-5.60$ & 14169 & $2.91 \pm 1.01$ & $1.20-4.10$ \\
\hline
\end{tabular}

$\mathrm{SD}=$ Standard deviation; $\mathrm{Cl}=$ Confidence interval

Table 3. Laterality of eye involvement in pterygium in all age groups

\begin{tabular}{lllllll}
\hline \multirow{2}{*}{$\begin{array}{l}\text { Age group } \\
\text { (years) }\end{array}$} & \multicolumn{2}{l}{ Male $(\mathrm{n}=188) \mathrm{n}(\%)$} & \multicolumn{2}{l}{ Female $(\mathrm{n}=235) \mathrm{n}(\%)$} & \multicolumn{2}{l}{ Male and Female $(\mathrm{n}=423) \mathrm{n}(\%)$} \\
\cline { 2 - 7 } Unilateral & Bilateral & Unilateral & Bilateral & Unilateral & Bilateral \\
\hline $40-39$ & $8 / 8(100.0)$ & $0 / 8(0.0)$ & $8 / 12(66.7)$ & $4 / 12(33.3)$ & $16 / 20(80.0)$ & $4 / 20(20.0)$ \\
$50-59$ & $30 / 36(83.3)$ & $6 / 36(16.7)$ & $39 / 53(73.6)$ & $14 / 53(26.4)$ & $69 / 89(77.5)$ & $20 / 89(22.5)$ \\
$60-69$ & $39 / 50(78.0)$ & $11 / 50(22.0)$ & $43 / 55(78.2)$ & $12 / 55(21.8)$ & $82 / 105(78.1)$ & $23 / 105(21.9)$ \\
$70-79$ & $40 / 55(72.7)$ & $15 / 55(27.3)$ & $41 / 50(82.0)$ & $9 / 50(18.0)$ & $81 / 105(77.1)$ & $24 / 105(22.9)$ \\
$>80$ & $5 / 7(71.4)$ & $2 / 7(28.6)$ & $18 / 32(56.2)$ & $14 / 32(43.8)$ & $23 / 39(59.0)$ & $16 / 39(41.0)$ \\
\hline Total & $144 / 188(76.6)$ & $44 / 188(23.4)$ & $175 / 235(74.5)$ & $60 / 235(25.5)$ & $319 / 423(75.4)$ & $104 / 423(24.6)$ \\
\hline
\end{tabular}


Pterygium was detected in 527 eyes of 423 patients (unilateral in 319 and bilateral in 104 patients). Right- and left-sided pterygiums were noted in 267 (50.7\%) and 260 (49.3\%) eyes, respectively. In these patients pterygiums were observed in nasal $(n=517$ eyes) and temporal $(n=10)$ regions of the eye (Table 4).

Table 4. Distribution of pterygium according to its location

\begin{tabular}{lccc}
\hline & $\begin{array}{c}\text { Right eye } \\
(\mathrm{n}=267) \\
\mathrm{n}(\%)\end{array}$ & $\begin{array}{c}\text { Left eye } \\
(\mathrm{n}=260) \\
\mathrm{n}(\%)\end{array}$ & $\mathrm{p}$ Value \\
\hline Nasal region & $263(49.9)$ & $254(48.2)$ & 0.945 \\
Temporal region & $4(0.76)$ & $6(1.14)$ & 0.856 \\
Nasal and & 0 & 0 & 1.00 \\
Temporal region & & 0 & \\
\hline
\end{tabular}

Distribution of 423 patients based on the stage of the pterygium was as follows: Stage 1, 14.1\%; Stage 2, 59.9\%; Stage 3, 7.2\%; Stage 4, 17.1\% and Stage 5, 1.7 percent. Any significant difference was not found between male and female patients with pterygiums in Stages $1(p=0.381), 2(p=0.363)$ and $4(p=0.160)$ and in all age groups. Patients with Stage 3 pterygiums in age groups of 30-39, 60-69 and $\geq 80$ years consisted of only female, while age group of 70-79 years constituted of only male patients with a statistically significant intergroup difference $(p=0.007)$ (Figure 2). All 3 patients in Stage 5 were of male gender.

Distance from the pterygium to the limbus in patients with pterygium was determined in different age groups as follows: $30-39$ yrs: $1.18 \pm 0.53 \mathrm{~mm}$; $40-49$ yrs: $1.06 \pm 0.60 \mathrm{~mm} ; 50-59$ yrs: $1.26 \pm 0.71 \mathrm{~mm}$; $60-69$ yrs: $1.43 \pm 0.68 \mathrm{~mm} ; 70-79$ yrs: $1.36 \pm 0.97 \mathrm{~mm}$ and $\geq 80$ yrs: $1.28 \pm 0.81 \mathrm{~mm}$.

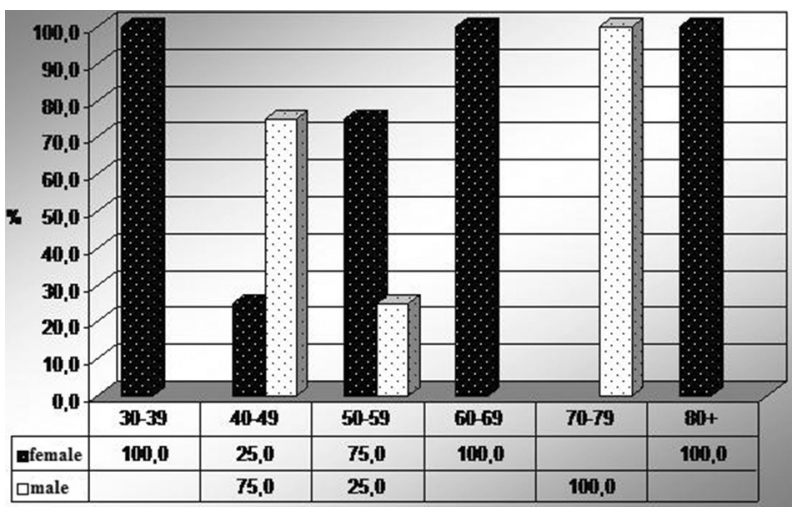

Figure 2. Distribution of Stage 3 patients according to age and gender of the patients

Mean distance from the pterygium to limbus was determined as $0.87 \pm 0.58 \mathrm{~mm}$. Distribution of the distance from the lesion to the limbus based on the different stages of the pterygium was found to be statistically significant $(p<0.001)$. Minimal and maximal distances from limbus to the lesion were measured in Stage $1(0.27 \pm 0.06 \mathrm{~mm})$ and Stage 5 $(2.71 \pm 0.24 \mathrm{~mm})$, respectively. Three hundred and six patients with pterygium had dark $(n=306$; brown or black) or light ( $n=96$ : all other eye colours) coloured eyes. Eye colour of the patient has no statistically significant impact on the development of pterygium $(p=0.860)$ (Table 5$)$.

Table 5. Distribution of distance between pterygium and limbus and light- and dark-coloured eyes in different stages of pterygium

\begin{tabular}{|c|c|c|c|c|c|c|c|}
\hline & $\begin{array}{c}\text { Total } \\
(n=402)\end{array}$ & $\begin{array}{l}\text { Stage } 1 \\
(n=55)\end{array}$ & $\begin{array}{l}\text { Stage } 2 \\
(n=250)\end{array}$ & $\begin{array}{l}\text { Stage } 3 \\
(n=26)\end{array}$ & $\begin{array}{c}\text { Stage } 4 \\
(n=68)\end{array}$ & $\begin{array}{c}\text { Stage } 5 \\
(n=3)\end{array}$ & $p$ Value \\
\hline $\begin{array}{l}\text { Distance from limbus } \\
\text { mean } \pm S D \text { (range) }\end{array}$ & $\begin{array}{c}0.87 \pm 0.58 \\
(0.01-4.08)\end{array}$ & $\begin{array}{c}0.27 \pm 0.06 \\
(0.09-0.42)\end{array}$ & $\begin{array}{c}0.73 \pm 0.31 \\
(0.01-1.84)\end{array}$ & $\begin{array}{c}1.0 \pm 0.35 \\
(0.59-2.23)\end{array}$ & $\begin{array}{c}1.74 \pm 0.61 \\
(0.82-3.52)\end{array}$ & $\begin{array}{l}2.71 \pm 0.24 \\
(2.56-3.0)\end{array}$ & $<0.001$ \\
\hline Light colored eye $\mathrm{n}(\%)$ & 96 & $12(21.8)$ & $60(24.0)$ & $6(23.1)$ & $18(26.5)$ & 0 & \multirow{2}{*}{0.860} \\
\hline Dark colored eye $\mathrm{n}(\%)$ & 306 & $43(78.2)$ & $190(76.0)$ & $20(76.9)$ & $50(73.5)$ & $3(100.0)$ & \\
\hline
\end{tabular}

SS = Standard deviation; ${ }^{*}=p<0.05$.

\section{DISCUSSION}

This study was planned to determine the incidence of pterygium, its relationship with age and gender of the patients, the impact of age and gender on the severity of the disease. In this study, incidence of pterygium was estimated as $2.91 \%$ in all age groups. Besides, the incidence of pterygium increases with age. In our male and female populations in all age groups, pterygium was observed in $1.75 \%$ and $3.67 \%$ of the cases, respectively. A significant difference in incidence rates favoring female patients in the age groups $40-49$ and $70-79$ years and male patients in the age group $\geq 80$ years has been revealed. Besides, pterygium was unilateral or bilateral in $75.4 \%$ and $24.6 \%$ of the patients, respectively. 
It affected right or left eyes of the patients in $50.7 \%$ and $49.3 \%$ of the cases, respectively. Incidence of unilateral, bilateral, right or left sided involvement did not differ between genders. Pterygiums were localized in nasal or temporal regions in $98 \%$ and $2 \%$ of the patients, respectively. Pterygiums detected in majority $(59.9 \%)$ of patients were consistent with Stage 2 pterygiums. Mean distance from the pterygium to limbus were longest in the age group of 60-69 years, but the lesion was nearest to the limbus in the age group of 40-49 years. Our study demonstrated that eye colour of the patient has no statistically significant impact on the development of pterygium.

Since studies on the prevalence of pterygium have been performed among patients who had consulted to the outpatient clinics, precise information on its incidence in the population is lacking. Besides, many factors can be influential on the discrepant rates of prevalence detected in the relevant investigations. These include diverse geographic, environmental and occupational factors, age distribution among the patient population of the study group, ethnic and racial variations which all complicate intergroup comparisons. In population-based studies reported prevalence of pterygium has ranged between 0.3 and 29 percent. Population based studies are very limited in number. Apart from screening studies performed in Solomon Islands, Singapore and Australia, relevant studies are lacking $[2,12,13]$. Global studies on the prevalence of pterygiums are conducted among patients who consulted to hospitals and prevalence rates varying between $0.7 \%$ and $31.1 \%$, have been detected [3-5]. In our study, median incidence rate of pterygium was estimated as $2.91 \%$ in all age groups which is in accordance with literature data.

Pterygium is rarely seen less than 15 years of age and its prevalence increases with age [14]. Median age at the onset of the lesion is 44 years, while its reported incidence peaks between 50 and 60 years of age $[15,16]$. In a population based screening study performed in Sumatra Island of Indonesia, prevalence of pterygium was $2.9 \%$ in the $21-29$-year old age group, while its prevalence was reportedly $17.3 \%$ in the age group of 50 years or older [17]. In African Saharan region, prevalence of pterygium was determined as $1.1 \%$ in the $2-19$ year-old age group, while its prevalence rose to $13 \%$ in the age group of 40-87 years [18]. In our study, mean age of the patients with pterygium was $61.91 \pm 13.26$ (range: $30-88$ years) years. Distribution of incidence rates of pterygium among respective age groups were as follows: $0.68 \%$ (30-39 years), $1.87 \%$ (40-49 years),
$2.49 \%$ (50-59 years), $4.19 \%$ (60-69 years), $8.19 \%$ ( $70-79$ years) and $9.44 \%$ ( $\geq 80$ years). In our study incidence of pterygium also increased with age in compliance with literature findings.

Even though gender of the patients seems to be a determining factor in the prevalence of pterygium, it is not always possible to evaluate its impact independently from the characteristics of the screened population, life style and environmental factors. In many studies, prevalence of pterygium has been detected higher among men than women $[13,19]$, however some literature studies like ours could not find a significant difference between genders $[4,17,20]$ or they noted higher incidence rates of pterygium among women $[21,22]$. In an Indonesian study, prevalence rates of pterygium were indicated as $17.6 \%$ in women and $16.1 \%$ in men [17]. In many countries, pterygium is more frequently observed among male population. These differences in incidence rates were attributed to men's working in outer environment. Prevalence rates of pterygium were found to be almost identical between genders in patient groups with similar life styles $[7,23,24]$. In our study, incidence of pterygium was observed to be $1.75 \%$ in male and $3.67 \%$ in female populations without any significant difference between genders. A statistically significant difference in incidence rates was detected favoring female patients in the age groups of 40-49 and 70-79 years and male patients in the age group of $\geq 80$ years. Metropolitan life style of Istanbul, active involvement of both genders in business life and outdoor occupations with similar exposure to environmental factors might possibly account for insignificant differences between genders as for the development of pterygium in all age groups.

Pterygium can be observed in one or both eyes (bilateral) of the same patient. In many studies the incidence of bilateral pterygiums has ranged between 4.13 and 67.3 percent [18]. In our study, uni- and bilateral pterygiums were seen in 75.4 and $24.6 \%$ of the cases and right and left eyes of our patients were affected $(50.7 \%$ and $49.3 \%$ of the patients, respectively). Besides laterality of the pterygium or involvement of one or both eyes were not affected by the gender of the patients. Bilateral pterygiums were detected most frequently in men aged between 40-49 years and also in women aged 80 years and over.

There is a consensus on the intraocular location of pterygium. Pterygium is mostly located on the nasal side and less frequently on the temporal side [25]. Also in our study, location of pterygium was located on nasal and temporal regions in $98 \%$ 
and $2 \%$ of the cases, respectively which is consistent with the most frequently observed pattern.

Discrepant opinions and methods exist related to the staging of pterygium. This controversial state presents challenges in sound comparative investigations about staging of pterygiums. In a study, most frequently Stage $4(46.5 \%)$, then second most frequently Stage 2 (26.5\%) pterygiums were observed [26]. However, Schellini et al. mostly encountered Stage 2 pterygiums $(69.6 \%)$ [27]. In our study, Stage $2(59.9 \%)$ and $4(17.1 \%)$ pterygiums ranked first and second in order of their frequencies. In Stages 1, 2 and 4, a significant difference was not observed in terms of gender differences among age groups of patients with pterygiums, while patients with Stage 3 pterygiums in age groups of 30-39, 6069 and $>80$ years were entirely comprised of female patients and those in the age group of 70-79 years consisted wholly of male cases. All patients with Stage 5 pterygiums were of male gender. Detection of pterygiums in their early stages will be advantageous regarding easier management of the disease with fewer complications. Generally lack of any impact of gender on stages of the pterygium distracts us away from the possible involvement of genderrelated genetic factors.

The most important disadvantage of this study is that it only encompassed patients who consulted to our out-patient clinics of ophthalmology. Hospital-based studies make it impossible to select a sampling, which can represent the whole population contrary to population-based studies and they also pose problems related to generalization of the outcomes of the investigation. Despite all of these limitations, we think that our study will contribute to the relevant literature.

In conclusion, incidence of pterygium for all age groups at a University hospital in Istanbul is $2.91 \%$. Risk of pterygium development increases with age. Incidence of pterygium differs between genders but without any significant difference. Gender of the patients did not affect unilateral or bilateral development of pterygium or predilection for the right or the left eye. Pterygium was observed in nasal $(98 \%)$ or (2\%) temporal regions. This study has also demonstrated that eye colour of the patients has no significant effect on the development of pterygium.

\section{REFERENCES}

1. Grimmett MR, Holland EJ. Management of pterygium. In: Krachmer JH, Mannis MJ, Holland EJ, eds. Cornea, Surgery of Cornea and conjunctiva. Mosby St. Louis Vol III, 1997;153:1873-1875.
2. Verlee DL. Ophthalmic survey in the Solomon Islands. Am J Ophthalmol 1968;66:304-319.

3. Saw SM, Tan D. Pterygium: prevalance, demography and risk factors. Ophthalmic Epidemiol 1999;6:219228.

4. Rojas Jr, Malaga H. Pterygium in Lima, Peru. Ann Ophthalmol 1986;18:147-149.

5. Forsius H, Maertens K, Fellman J. Changes of the eye caused by the climate in Rwanda, Africa. Ophthalmic Epidemiol 1995;2:107-113.

6. Detels R, Dhir SP. Ptergium: A geophraphical study. Arch Ophthalmol 1967;78:485-491.

7. Moran DJ, Hollows FC. Ptergium and ultraviolet radiation: a positive corelation. $\mathrm{Br} \mathrm{J}$ Ophthalmol 1984;68:343-346.

8. Mackenzie FD, Hirsh LW, Battistutta D, Gren A. Risk anlaysis in the development of ptergia. Ophthalmology 1992;99:1056-1061.

9. Taylor HR. Studies on tear film in climatic droplet keratopathy and ptergium. Arch Ophthalmol 1980;98:8688.

10. Waller SG, Adamis AP. Ptergium. In: Tasman W, Jaeger EA, eds. Duane's Clinical Ophthalomology. Lippincott Comp. Philedelphia. 1994, Chapter 35, 1-13.

11. Bilek B, Keklikçi U, Şakalar YB, et al. Comparison of Amniotic Membrane Grafts and Intraoperative Mitomycin C for Primary Pterygium Excision. Dicle Med J 2008;35: 44-49.

12. Lim R, Mitchell P, Cumming RG. Cataract associations with pinguecula and pterygium: the Blue Mountains Eye Study. Am J Ophthalmol 1998;126:717-719.

13. Wong TY, Foster PJ, Johnson GJ, et al. The prevalence and risk factors for pterygium in an adult Chinese population in Singapore: the Tanjong Pagar survey. Am J Ophthalmol 2001;131:176-183.

14. Hilgers JHC. Pterygium: its insidence, heredity and etiology. Am J Ophthalmol 1960;50:635-644.

15. Buratto L, Phillips RL, Carito G. Pterygium Surgery, Thorofare: Slack Incorporated, 2000.

16. Duke-Helder S. Pterygium. In: Duke-Helder. Diseases of the outer eye. Conjunctiva. In: System of ophthalmology, vol 8; pt.1, St. Louis, C.V Mosby, 1965:573585.

17. Gazzard G, Saw SM, Farook M, et al. Pterygium in Indonesia: prevalence, severity and risk factors. $\mathrm{Br} \mathrm{J}$ Ophthalmol 2002;86:1341-1346.

18. Bueno-Gimeno I, Montes-Mico R, Espana-Gregori E, Pons AM. Epidemiologic study of pterygium in a Saharan population. Ann Ophthalmol 2002;34:43-46.

19. McCarty C, Fu CL, Taylor HR. Epidemiology of pterygium in Victoria, Australia. $\mathrm{Br} \mathrm{J}$ Ophthalmol 2000;84:289-292.

20. Luthra R, Nemesure BB, Wu SY, et al. Frequency and risk factors for pterygium in the Barbados Eye Study. Arch Ophthalmol 2001; 119:1827-1832.

21. Wu K, He M, Xu J, Li S. Pterygium in aged population in Doumen County, China. Yan Ke Xue Bao 2002;18:181-184. 
22. Lu $\mathrm{P}$, Chen $\mathrm{X}$, Kang $\mathrm{Y}$, et al. Pterygium in Tibetans: a population-based study in China. Clin Experiment Ophthalmol 2007;35:828-833.

23. Taylor HR. Aetiology of climatic droplet keratopathy and pterygium. Br J Ophthalmol 1980; 64:154-163.

24. Taylor HR, West S, Munoz B, et al. The long-term effects of visible light on the eye. Arch Ophthalmol 1992;110:99-104.
25. Hill JC, Maske R. Pathogenesis of pterygium. Eye 1989;3:218-226.

26. Liang QF, Xu L, Jin XY, et al. Epidemiology of pterygium in aged rural population of Beijing, China. Chin Med J (Engl) 2010;123:1699-1701.

27. Schellini SA, dos Reis Veloso CE, Lopes W, et al. Characteristics of patients with pterygium in the Botucatu region. Arq Bras Oftalmol 2005;68:291-294. 